\title{
Analisis Sensitivitas Model Epidemi SEIR
}

\section{Sensitivity Analysis of Seir Epidemic Model}

\author{
Roberta U. Hurint, Meksianis Z. Ndii*), Maria Lobo \\ Jurusan Matematika, Fakultas Sains dan Teknik, Universitas Nusa Cendana
}

\begin{abstract}
A sensitivity analysis of SEIR (Susceptible, Exposed, Infectious and Recovered) epidemic model was conducted to determine the influential parameters on the basic reproduction number and endemic equilibrium. We found that the transmission rate and recovery rate are the most influential parameters on the basic reproduction number, where the latter is also influential parameter on the number of infectious individuals. In addition, the number of exposed individuals is sensitive to the progression rate from exposed to infectious class. The results suggest that when infectious individuals recover faster, the number of infectious individuals could be reduced.
\end{abstract}

Key word: Mathematical Model, Sensitivity Analysis, SEIR Model

\begin{abstract}
ABSTRAK
Analisis sensitivitas dari model epidemi Susceptible, Exposed, Infectious dan Recovered (SEIR) dilakukan untuk mengetahui pengaruh perubahan nilai parameter terhadap nilai basic reproduction number dan titik tetap endemik khususnya kelas exposed and infectious. Hasil analisis menunjukkan bahwa laju transmisi penyakit dan laju kesembuhan merupakan parameter yang paling berpengaruh terhadap basic reproduction number. Sementara itu, laju perpindahandari kelas exposed ke infectious merupakan parameter yang sangat berpengaruh pada jumlah individu exposed. Laju kesembuhan merupakan parameter yang berpengaruh terhadap populasi dari kelas infectious. Hasil ini mengimplikasikan bahwa untuk mengurangi epidemi suatu penyakit maka perlu intervensi kesehatan yang dapat mempercepat kesembuhan individu terinfeksi (infectious inviduals).
\end{abstract}

Kata Kunci: Model Matematika, Analisis Sensitivitas, SEIR

\section{LATAR BELAKANG}

Pemodelan matematika untuk epidemi penyakit menular telah banyak digunakan untuk menganalisis dinamika penyebaran penyakit (Ndii dkk., 2015, Ndii dkk., 2016a, Ndii dkk., 2016b, Keeling dan
Rohani, 2007, Supriatna dkk., 2008).

Model-model matematika berbeda-beda tergantung karakteristik penyakit. Umumnya populasi tersebut dikelompokkan kedalam kelas-kelas sesuai dengan status kesehatannya (Ndii dkk., 
2015, Ndii dkk., 2016a, Keeling dan Rohani, 2007).

Salah satu model yang digunakan untuk menganalisis dinamika penyebaran penyakit adalah model SEIR, dimana populasi dikelompokkan kedalam kelas Susceptible (S), Exposed (E), Infectious (I) dan Recovered (R). Bentuk model ini diformulasi untuk tipe penyakit yang masa inkubasinya panjang. Ini dimaksudkan agar pengaruh masa inkubasi terhadap dinamika penyebaran penyakit dapat dianalisis. Pemahaman tentang hal ini penting karena dalam masa inkubasi, individu telah terserang virus tersebut tetapi belum dapat menularkannya kepada individu lain. Hal tersebut dapat mempengaruhi dinamika penyebaran penyakit.

Meskipun model SEIR ini telah banyak digunakan, belum banyak analisis sensitivitas dilakukan untuk mengetahui pengaruh perubahan nilai parameter terhadap variabel-variabel tertentu seperti basic reproduction number, populasi exposed dan infectious. Hal tersebut penting untuk mengetahui parameter mana saja yang berpengaruh besar terhadap dinamika dari model epidemi tersebut. Oleh karena itu, dalam artikel ini, analisis sensitivitas dari model epidemi SEIR dilakukan. Analisis difokuskan pada parameter-parameter dari basic reproductive ratio dan titik tetap endemik khususnya kelas exposed dan infectious.

\section{METODE}

\section{Model Matematika}

Dalam model SEIR, populasi dibagi kedalam empat sub-populasi yakni Susceptible (S), Exposed (E), Infectious (I) dan Recovered (R). Individu susceptible menjadi exposed apabila berinteraksi dengan individu terinfeksi (infectious) dengan laju $\beta$. Individu ter-exposed menjadi infectious dengan laju $\alpha$ kemudian recover dengan laju $\gamma$.

$$
\begin{aligned}
& \frac{d S}{d t}=\mu N-\frac{\beta I S}{N}-\mu S, \\
& \frac{d E}{d t}=\frac{\beta I S}{N}-\alpha E-\mu E, \\
& \frac{d I}{d t}=\alpha E-\mu I-\gamma I, \\
& \frac{d R}{d t}=\gamma I-\mu R .
\end{aligned}
$$

Pada Model (1), populasi diasumsikan konstan $N=S+E+I+R$ sehingga laju kelahiran dan kematian alami diasumsikan konstan. Model tersebut mempunyai dua titik ekuilibrium yakni titik dimana tidak ada penyakit dalam populasi atau dikenal dengan titik bebas penyakit dan titik dimana penyakit selalu ada dalam populasi atau yang dikenal dengan titik endemik. Titik bebas penyakit (disease-free equilibrium) adalah $\left(S^{*}, E^{*}, I^{*}, R^{*}\right)=$ 
$\left(\frac{A}{\mu}, 0,0,0\right)$ dan titik endemik (endemic equilibrium) adalah sebagai berikut:

$S^{*}=\frac{N\left(\beta \gamma+\beta \mu+\gamma \mu+\mu^{2}\right)}{\alpha \beta}$,

$E^{*}=-\frac{\mu N\left(-\alpha \beta+\beta \gamma+\beta \mu+\gamma \mu+\mu^{2}\right)}{\beta(\beta+\mu) \alpha}$,

$I^{*}=-\frac{\mu N\left(-\alpha \beta+\beta \gamma+\beta \mu+\gamma \mu+\mu^{2}\right)}{\alpha\left(\beta \gamma+\beta \mu+\gamma \mu+\mu^{2}\right)}$,

$R^{*}=-\frac{\gamma N\left(\alpha \beta+\beta \gamma+\beta \mu+\gamma \mu+\mu^{2}\right)}{\alpha\left(\beta \gamma+\beta \mu+\gamma \mu+\mu^{2}\right)}$.

Dengan mengonstruksi next generation matrix dan mencari nilai eigen terbesar dari matriks tersebut maka diperoleh nilai eigen terbesar adalah

$$
\begin{aligned}
& R_{0}=\frac{\alpha \beta}{(\gamma+\mu)(\alpha+\mu)} \\
& =\frac{\alpha \beta}{\alpha \gamma+\alpha \mu+\gamma \mu+\mu^{2}} .
\end{aligned}
$$

Persamaan (2) diatas dikenal dengan basic reproduction number/ratio.

Hasil analisis menunjukkan bahwa jika $R_{0}<1$ maka titik ekuilibrium bebas penyakit stabil asimptotik lokal. Jika $R_{0}>$ 1 maka titik endemik stabil asimptotik lokal (Keeling dan Rohani, 2007).

\section{Analisis Sensitivitas}

Penelitian ini difokuskan pada analisis sensitivitas dari parameterparameter terhadap basic reproduction number, dan titik endemik kelas exposed dan infectious. Ada dua jenis analisis sensitivitas yakni analisis sensitivitas lokal dan global (Marino dkk., 2008, Blower dan Dowlatabadi, 1994). Oleh karena jumlah parameter dari model yang tidak banyak maka penelitian ini difokuskan pada analisis sensitivitas lokal. Analisis dilakukan untuk mengetahui pengaruh perubahan nilai parameter terhadap nilai basic reproduction ratio $\left(R_{0}\right)$, titik endemik $\left(E^{*}, I^{*}\right)$.

Definisi 2.2. Normalized sensitivity index diperoleh dengan indeks sensitivitas normalisasi dari variabel $V$, terdiferensialkan pada parameter p, didefinisikan sebagai berikut:

$$
C_{p}^{V}=\frac{\partial V}{\partial p} \times \frac{p}{V}
$$

dimana $V$ adalah variabel yang akan dianalisis dan $p$ adalah parameter (Chitnis dkk., 2008).

\section{HASIL DAN PEMBAHASAN}

Pada bagian ini akan dilakukan analisis sensitivitas untuk mengetahui parameter-parameter yang berpengaruh terhadap variabel $R_{0}, E^{*}$ dan $I^{*}$. Indeks sensitivitas akan menginformasikan pengaruh parameter-parameter terhadap epidemi dari suatu penyakit (Chitnis dkk., 2008). Dalam analisis, nilai parameter yang digunakan adalah sebagai berikut. Laju transmisi $\beta=1.428$ (Keeling dan Rohani, 
2007), laju kesembuhan $\gamma=1 / 7$ (Keeling dan Rohani, 2007), laju transisi dari kelas exposed ke infectious $\alpha=1 / 8$ (Keeling dan Rohani, 2007) dan kematian alami $\mu=$ $1 /(365 \times 65)($ BPS,$\quad 2015)$ dan $\quad N=$ 100000. Nilai tersebut menghasilkan nilai basic reproduction number $R_{0}=9,998$ yang mengindikasikan tingginya level endemik suatu penyakit. Oleh karena itu, analisis ini diasumsikan dilakukan pada daerah dengan tingkat endemik tinggi. Hasil analisis menunjukkan bahwa untuk wilayah dengan tingkat endemik tinggi laju transmisi penyakit dan laju kesembuhan merupakan parameter yang paling berpengaruh terhadap basic reproduction number. Laju kesembuhan merupakan parameter yang berpengaruh terhadap populasi dari kelas infectious. Laju perpindahan dari kelas exposed ke infectious merupakan parameter yang sangat berpengaruh pada jumlah individu exposed.

\section{Analisis Sensitivitas $\boldsymbol{R}_{\mathbf{0}}$}

Pada bagian ini akan dianalisis kesensitifan parameter-parameter terhadap basic reproduction number (Persamaan 2). Indeks sensitivitas dari parameter $\alpha, \beta, \gamma$ terhadap $R_{0} \quad$ diperoleh dengan menggunakan Persamaan (3) dan hasilnya disajikan didalam Tabel 1. Indeks sensitivitas untuk parameter $\beta$ diperoleh dengan

$$
\begin{aligned}
C_{\beta}^{R_{0}} & =\frac{\partial R_{0}}{\partial \beta} \times \frac{\beta}{R_{0}} \\
& =\frac{\alpha}{(\gamma+\mu)(\alpha+\mu)} \times \frac{\beta(\gamma+\mu)(\alpha+\mu)}{\alpha \beta} \\
& =1
\end{aligned}
$$

Cara/prosedur yang sama dilakukan untuk menghitung indeks sensitivitas bagi parameter lainnya. Hasilnya disajikan pada Tabel 1.

Hasil analisis menunjukkan bahwa laju transmisi $(\beta)$ dan laju kesembuhan $(\gamma)$ merupakan dua parameter yang paling berpengaruh terhadap perubahan nilai $R_{0}$. Parameter $\beta$ memiliki relasi positif sedangkan parameter $\gamma$ memiliki relasi negatif. Artinya, jika nilai parameter $\beta$ maka nilai $R_{0}$ juga akan naik. Sebaliknya, jika nilai parameter tersebut turun, makan nilai $R_{0}$ juga turun. Hal sebaliknya berlaku untuk parameter $\gamma$. Jika parameter $\gamma$ naik maka nilai $R_{0}$ turun sebaliknya maka nilai $R_{0}$ akan naik. Selain itu, naik dan turunnya nilai $R_{0}$ sesuai dengan besaran indeks sensitivitasnya. Sebagai contoh, kenaikan $5 \%$ pada nilai $\beta$ berdampak pada kenaikan nilai $\quad R_{0} \quad$ sebesar $5 \% \times$ indeks sensitivitas dari parameter $\beta$. 
Tabel 1.Parameter, persamaan dan nilai indeks sensitivitas, dan perubahan nilai $R_{0}$. Jika terjadi perubahan nilai parameter. $p+5 \%$ berarti nilai parameter bertambah $5 \%$ dari nilai sebelumnya. $p-5 \%$ berarti bahwa nilai parameter berkurang $5 \%$ dari nilai sebelumnya. Nilai $R_{0}=9,989$.

\begin{tabular}{|c|c|c|c|c|}
\hline \multirow[t]{2}{*}{ Parameter } & \multirow[t]{2}{*}{ Persamaan } & \multirow[t]{2}{*}{ Nilai } & $\begin{array}{l}\boldsymbol{p} \\
+\mathbf{5} \%\end{array}$ & $p-5 \%$ \\
\hline & & & \multicolumn{2}{|c|}{ Nilai $R_{0}$} \\
\hline$\beta$ & 1 & +1 & 10,488 & 9,491 \\
\hline$\alpha$ & $1-\frac{\alpha}{(\alpha+\mu)}$ & $\begin{array}{r}+3,37 \\
\times 10^{-4}\end{array}$ & 9,989 & 9,989 \\
\hline$\gamma$ & $\frac{-\gamma}{(\gamma+\mu)}$ & $-0,997$ & 9,514 & 10,515 \\
\hline
\end{tabular}

\section{Analisis Sensitivitas $E^{*}$}

Indeks sensitivitas untuk parameter $\beta$ diperoleh dengan menggunakan formula indeks sensitivitas pada Persamaan (3).

$$
\begin{aligned}
\frac{\partial E^{*}}{\partial \beta}= & \frac{\mu N \alpha\left(\alpha^{2} \beta+\alpha \mu \beta\right)+\mu N\left(-\alpha \beta+\alpha \gamma+\alpha \mu+\gamma \mu+\mu^{2}\right)\left(\alpha^{2}+\alpha \mu\right)}{\left(\alpha^{2} \beta+\alpha \mu \beta\right)^{2}}, \\
& =\frac{\mu N \alpha-E^{*}\left(\alpha^{2}+\alpha \mu\right)}{\left(\alpha^{2} \beta+\alpha \mu \beta\right)} .
\end{aligned}
$$

Sehingga

$$
\begin{aligned}
C_{\beta}^{E^{*}} & =\frac{\partial E^{*}}{\partial \beta} \times \frac{\beta}{E^{*}} \\
& =\frac{\mu N \alpha-E^{*}\left(\alpha^{2}+\alpha \mu\right)}{\left(\alpha^{2} \beta+\alpha \mu \beta\right)} \times \frac{\beta}{E^{*}} \\
& =\frac{\mu N \alpha \beta}{E^{*}\left(\alpha^{2} \beta+\alpha \mu \beta\right)}-1 .
\end{aligned}
$$

Indeks sensitivitas untuk parameter lainnya dapat dilakukan dengan prosedur yang sama dan hasilnya diberikan pada Tabel 2. Hasil analisis menunjukkan bahwa parameter laju transmisi merupakan parameter yang paling berpengaruh terhadap populasi exposed adalah laju transisi dari populasi exposed ke infectious, $\alpha$.

\section{Analisis Sensitivitas I* \\ Indeks sensitivitas dari parameter} untuk populasi infectious diperoleh dengan prosedur yang sama seperti sebelumnya dan hasilnya diberikan pada Tabel 3. Hasil analisis menunjukkan bahwa parameter $\gamma$ merupakan dua parameter yang sangat berpengaruh terhadap $I^{*}$ dan memiliki relasi negatif. Jika nilai parameter $\gamma$ meningkat maka jumlah populasi infectious akan menurun dan sebaliknya jika nilai parameter $\gamma$ menurun maka jumlah populasi infectious meningkat.

Hasil ini mengindikasikan bahwa laju kesembuhan merupakan faktor yang menentukan 
epidemi suatu penyakit. Ini berarti bahwa maka penularan suatu penyakit dapat jika ada intervensi yang dapat dilakukan ditekan.

untuk mempercepat waktu kesembuhan

Tabel 2. Parameter, persamaan dan nilai indeks sensitivitas, dan perubahan nilai $E^{*}$ jika terjadi perubahan nilai parameter. $p+5 \%$ berarti nilai parameter bertambah $5 \%$ dari nilai sebelumnya. $p-5 \%$ berarti bahwa nilai parameter berkurang $5 \%$ dari nilai sebelumnya. Nilai $E^{*}=30,334$.

\begin{tabular}{|l|c|c|c|c|}
\hline Parameter & Persamaan Indeks Sensitivitas & Nilai Indeks & $p+5 \%$ & $p-5 \%$ \\
& & Sensitivitas & & \\
\cline { 3 - 5 } & & & \multicolumn{2}{|c|}{ NILAI $E^{*}$} \\
\hline $\boldsymbol{\alpha}$ & $\frac{\alpha \beta}{\alpha \beta-\alpha \gamma-\alpha \mu-\gamma \mu-\mu^{2}}-1$ & $\mathbf{0 , 1 1 1}$ & $\mathbf{3 0 , 4 9 4}$ & $\mathbf{3 0 , 1 5 6}$ \\
\hline$\gamma$ & $\frac{\alpha(\beta-\gamma-\mu)}{\alpha(\beta-\gamma-\mu)-\mu(\gamma+\mu)}-\frac{2 \alpha+\mu}{\alpha+\mu}$ & $\mathbf{- 0 , 9 9 9}$ & $\mathbf{2 8 . 8 9 0}$ & $\mathbf{3 1 , 9 2 9}$ \\
\hline & $\frac{\gamma(\alpha+\mu)}{-\alpha \beta+\alpha \gamma+\alpha \mu+\gamma \mu+\mu^{2}}$ & $\mathbf{- 0 , 1 1 1}$ & $\mathbf{3 0 , 1 6 5}$ & $\mathbf{3 0 , 5 0 2}$ \\
\hline
\end{tabular}

Tabel 3. Parameter, persamaan dan nilai indeks sensitivitas, dan perubahan nilai $I^{*}$ jika terjadi perubahan nilai parameter. $p+5 \%$ berarti nilai parameter bertambah $5 \%$ dari nilai sebelumnya. $p-5 \%$ berarti bahwa nilai parameter berkurang 5\% dari nilai sebelumnya. Nilai $I^{*}=26,534$.

\begin{tabular}{|c|l|c|c|c|}
\hline $\begin{array}{l}\text { Paramete } \\
\mathbf{r}\end{array}$ & Persamaan Indeks Sensitivitas & Nilai Indeks & $p+5 \%$ & $p-5 \%$ \\
& & Sensitivitas & & \\
\cline { 4 - 5 } & & & \multicolumn{2}{|c|}{ Nilai $I^{*}$} \\
\hline$\beta$ & $\frac{-\alpha \beta}{-\alpha \beta+\alpha \gamma+\alpha \mu+\gamma \mu \mp \mu^{2}}-1$ & $+0,111$ & $\mathbf{2 6 , 6 7 0}$ & $\mathbf{2 6 , 3 7 9}$ \\
\hline$\alpha$ & $\frac{\alpha(-\beta+\gamma+\mu)}{-\alpha \beta+\alpha \gamma+\alpha \mu+\gamma \mu+\mu^{2}}-\frac{\alpha(\gamma+\mu)}{\alpha \gamma+\alpha \mu+\gamma \mu+\mu^{2}}$ & $+0,0003$ & $\mathbf{2 6 , 5 3 4}$ & $\mathbf{2 6 , 5 3 4}$ \\
\hline$\gamma$ & $\frac{\gamma(\alpha+\mu)}{-\alpha \beta+\alpha \gamma+\alpha \mu+\gamma \mu+\mu^{2}}-\frac{\gamma(\alpha+\mu)}{\alpha \gamma+\alpha \mu+\gamma \mu+\mu^{2}}$ & $-1,110$ & $\mathbf{2 5 , 1 3 0}$ & $\mathbf{2 8 , 0 8 5}$ \\
\hline
\end{tabular}

Hasil analisis menunjukkan bahwa laju transmisi $\beta$ dan laju kesembuhan $\gamma$ merupakan dua parameter yang berpengaruh pada basic reproduction number $R_{0}$. Parameter yang pertama $(\beta)$ memiliki hubungan positif sedangkan parameter yang kedua $(\gamma)$ memiliki hubungan negatif. Hasil ini mengindikasikan bahwa laju transmisi dan laju kesembuhan sangat berpengaruh terhadap epidemi suatu penyakit dalam populasi. Jika laju transmisi sangat besar maka laju kesembuhan juga harus besar. Jika laju transmisinya kecil dan laju 
kesembuhannya besar maka epidemi penyakit tidak akan terjadi dalam populasi. Analisis ini difokuskan pada daerah dengat tingkat endemik tinggi yang digambarkan dari besarnya nilai $R_{0}$. Sehingga dapat disimpulkan bahwa untuk daerah dengan tingkat endemik tinggi, maka diperlukan suatu intervensi yang dapat mempercepat kesembuhan individu terinfeksi (infectious individuals). Sedangkan, untuk populasi exposed dan infectious, laju transisi keluar dari kelasnya merupakan parameterparameter yang paling berpengaruh terhadap populasinya dan memiliki relasi negatif. Sebagai contoh, laju transisi dari kelas exposed ke infectious merupakan parameter yang berpengaruh terhadap populasi exposed. Laju kesembuhan merupakan parameter yang paling berpengaruh terhadap populasi infectious. Hasil ini menunjukkan bahwa untuk dapat mengurangi jumlah individu terinfeksi dalam populasi maka laju kesembuhan harus besar. Dengan kata lain perlu intervensi yang dilakukan untuk mempercepat kesembuhan individu terinfeksi. Hasil ini sejalan dengan analisis pengaruh parameter terhadap basic reproduction number, $R_{0}$.

\section{DAFTAR PUSTAKA}

Blower, S. M.dan Dowlatabadi, H. 1994. Sensitivity and Uncertainty Analysis of Complex Models of Disease Transmission: An HIV
Model, as an Example. International Statistical Review / Revue Internationale de Statistique, 62, 229-243.

BPS 2015. Angka Harapan Hidup (AHH) menurut Jenis Kelamin dan Provinsi, 2010-2014. https://www.bps.go.id/linkTableDin amis/view/id/1114.

Chitnis, N., Hyman, J. M.dan Cushing, J. M. 2008. Determining Important Parameters in the Spread of Malaria Through the Sensitivity Analysis of a Mathematical Model. Bulletin of Mathematical Biology, 70, 1272.

Keeling, M. J.dan Rohani, P. 2007. Modeling Infectious Diseases in Humans and Animals, Princeton University Press.

Marino, S., Hogue, I. B., Ray, C. J.dan Kirschner, D. E. 2008. A methodology for performing global uncertainty and sensitivity analysis in systems biology. Journal of Theoretical Biology, 254, 178-196.

Ndii, M. Z., Allingham, D., Hickson, R. I.dan Glass, K. 2016a. The effect of Wolbachia on dengue dynamics in the presence of two serotypes of dengue: symmetric and asymmetric epidemiological characteristics. Epidemiology and Infection, 144, 2874-2882.

Ndii, M. Z., Allingham, D., Hickson, R. I.dan Glass, K. 2016b. The effect of Wolbachia on dengue outbreaks when dengue is repeatedly introduced. Theoretical Population Biology, 111, 9-15.

Ndii, M. Z., Hickson, R. I., Allingham, D.dan Mercer, G. N. 2015. Modelling the transmission dynamics of dengue in the presence of Wolbachia. Mathematical Biosciences, 262, 157-166.

Supriatna, A. K., Soewono, E.dan van Gils, S. A. 2008. A two-age-classes dengue transmission model. Mathematical Biosciences, 216, 114-121. 